\title{
The implications of the impact of the recreational use of forest mining ponds on benthic invertebrates with special emphasis on gastropods
}

\author{
Aneta Spyra $^{1}$ (D) $\cdot$ Małgorzata Strzelec ${ }^{1}$
}

Received: 16 November 2018 / Accepted: 15 February 2019 / Published online: 21 March 2019

(C) The Author(s) 2019

\begin{abstract}
The relationships between the distribution and diversity patterns of benthic invertebrates in forest ponds used for different recreational activities were examined in this study. The study was based on sampling of benthic invertebrates, plant coverage, physical and chemical analysis of water samples and multivariate species analysis. Mining ponds varied in their solution chemistry and plant cover, with those used for recreation having significantly lower invertebrate occurrences $\left(755\right.$ ind. $\left.\mathrm{m}^{-2}\right)$ compared to ponds with no recreational use ( 2629 ind. $\mathrm{m}^{-2}$ ). Statistically significant differences were also observed in the density of Oligochaeta, Hirudinea, Coleoptera, Trichoptera and Diptera between the two types of ponds. Overall, gastropods were more diverse and abundant in ponds not used for recreation. This appeared to relate strongly to plant cover, since cover was greatly reduced in recreational ponds, although plant diversity was enhanced. Density and diversity of benthic invertebrates was also observed to differ in relation to the kind of recreational use involved (recreational angling, swimming, power boating) although this was not quantified. The occurrence of freshwater snails primarily depended on the Ca concentration, the conductivity of the water and plant cover, but recreational disturbance appeared to reduce abundance where it occurred and was related to a reduction in overall plant cover.
\end{abstract}

Keywords Recreation $\cdot$ Benthos fauna $\cdot$ Snails $\cdot$ Anthropogenic ponds $\cdot$ Forest subsidence habitats

\section{Introduction}

During the past century, huge changes have occurred in recreation (Liddle and Scorgie 1980; Anderson 2013; Knight and Temple 2013). Along with the urbanisation processes, it is expected that outdoor recreational activity will continue to increase, and this requires humans to protect the biological diversity due to the implications for nature (Anderson 2013).

Artificial lakes from industrial activities are increasingly being reclaimed as recreational water bodies. In Europe, including the Upper Silesian Coal Basin in southern Poland a high concentration of small anthropogenic ponds has been ob-

Aneta Spyra

aneta.spyra@us.edu.pl

1 Department of Hydrobiology, Faculty of Biology \& Environmental Protection, University of Silesia, Bankowa 9, 40-007 Katowice, Poland served (Rychała et al. 2011). These ponds were created in subsidence basins (land depressions) due to the underground exploitation of raw materials, primarily coal, and are now a permanent part of the industrial landscape (Rzętała et al. 2006; Machowski and Noculak 2014). Their number and depth depends on the intensity of the human economic activity, and this alters the public use of their waters for recreation. Being formed in random locations due to the unintentional human activity, they often occur in areas regarded as wastelands, forest complexes (Spyra and Strzelec 2014) or in areas with urban agglomerations (Dąbrowska and Dąbrowski 2015; Dąbrowska and Soltysiak 2015). They are filled by groundwater, precipitation, and surface runoff, and many of them are also stocked with fish. Their ensure migration corridors (De Meester et al. 2005) and contribute to the preservation of the regional diversity of aquatic biota (Biggs et al. 1994; Oertli et al. 2002; Grochowska et al. 2004; Pakulnicka 2008; Rychała et al. 2011; Céréghino et al. 2014). As long as they can be used for recreational purposes, they are taken into account in land spatial planning due to the fact that the popularity 
of recreational activities that involve contact with water has increased (Monz et al. 2013). Located in forests, they constitute many recreational attractions in the industrial landscape of southern Poland. The recreational use of these ponds primarily includes fishing, swimming, motor boating, canoeing, and bird feeding. People have an impact on habitats no matter what activity they undertake, and, during the waterfowl breeding season, anglers contribute to a serious decline in breeding waterfowl. Fishing is considered to be one of the most interactive factors in the recreational use of ponds. Intensive angling can alter the benthos richness (Anderson 2013).

Benthic invertebrates constitute an important food source for many predators, including crayfish, water bugs, leeches, flatworms, insectivorous birds, and fish (Brönmark and Malmqvist 1986; Nyström and Perez 1998; Kristd 2002). The presence of molluscivorous fish can seriously reduce the population density of snails (Brönmark et al. 1992; Lakowitz et al. 2008), as a significant element of food webs (Brown et al. 1998; Turner and Chislock 2007). Fish are known to reduce the abundance of invertebrates. Studies have frequently been carried out in aquatic environments that were regularly stocked with fish (McNicol and Wayland 1992; Epler et al. 2010) or in experimental studies (Manatunge et al. 2000; Winkelmann et al. 2011), and their results obviously indicate the impoverishment of invertebrates due to predation by fish.

An awareness of the value of anthropogenic freshwater ecosystems leads, more often, to the use of good practices in their management because of their ecological value (Jankowski and Czylok 2008). Despite their potentially high abundance, serious gaps in our knowledge of benthos assemblages and the factors that affect their occurrence in water bodies that are used for recreation exist (Machowski 2010). It seems that the impact of recreation will be greater than in lakes due to the small size of these environments.

Some limitations and difficulties determining the impact of recreation are known regarding the complexity of the roles of humans and nature in ecosystems, because some impacts can occur due to natural fluctuations and disturbances associated with recreational use. Most papers only concern this impact on single species (Gutzwiller 2013; Vaske et al. 2013). Determining how particular types of recreation affect the benthos is complicated and rather difficult to explain, because it is related to the intensity of the recreational activity and is also connected with the environmental conditions. Therefore, in our study, we primarily focused on the recreational use of ponds compared to ponds in which there are no recreation activities and the differences in the density and diversity of invertebrates, water chemistry, and aquatic macrophytes richness and cover in relation to the recreational use of ponds in forests. In view of the possible impact of the recreational use of ponds on benthic invertebrates our study was undertaken to answer the following questions:
1. Does anthropogenic habitat use affect the invertebrate assemblages including snails?

2. Are there any significant differences in the density and diversity of benthic invertebrates including snails, and between the ponds that are, or are not, used recreationally?

3. Does the recreational use of ponds cause differences in environmental conditions for the occurrence of aquatic invertebrates including the snails?

\section{Material and methods}

\section{Study area description}

The research was conducted in an area that is associated with a specific type of human economic activity in the Upper Silesian Coal Basin (Southern Poland) (Fig. 1). This region is currently perceived as one of the most urbanised parts of Poland, which has an area of about $5500 \mathrm{~km}^{2}$ (Janson et al. 2009) and is called the "lake district of Southern Poland" or an "Anthropogenic Lakeland" because of the numerous, humanmade water environments. The ponds in this study belong to the subsidence water bodies that formed as a result of many years of mining activity on this territory. They are also known as "small mining lakes" or "anthropogenic lakes" (Rychała et al. 2011; Rzętała and Jaguś 2012). Being formed in subsidence basins (troughs) in forested mining areas, they form a characteristic element of the industrial landscape. The formation of the basins is the result of the deflection and downward movement of the rock layers that are situated at deep levels in the areas where underground mining activity occurs. In this area, many of the anthropogenic water bodies are intensively used for various types of recreation, e.g., as wild fisheries for recreational angling, swimming, power boating, feeding birds, canoeing, etc. They have different area (from 0.4 ha to $20 \mathrm{ha}$ ) and depths (mean depth from $1.3 \mathrm{~m}-3.0 \mathrm{~m}$ ). Their size depends on the intensity of the process of the land subsidence and drainage activities that have been undertaken, especially in areas that are earmarked for urban planning and development. The use of the surrounding land affects the quality of their waters (Jankowski and Czylok 2008). Mining ponds have forested shorelines, they are permanent and do not differ in terms of fluctuations in their water levels.

For this study, 16 forest mining ponds were selected -8 mining ponds which are used for various type of recreation (RUP - Recreationally Used Ponds) and 8 mining ponds with no recreational use (CGP - Control Group Ponds). RUP are used as wild fisheries and were artificially stocked with fish, mostly with common species of cyprinids: Cyprinus carpio (Linnaeus, 1758), Tinca tinca (Linnaeus, 1758), Carassius carassius (Linnaeus, 1758), Rutilus rutilus (Linnaeus, 1758), Scardinius erythrophthalmus (Linnaeus, 1758), Leucis 


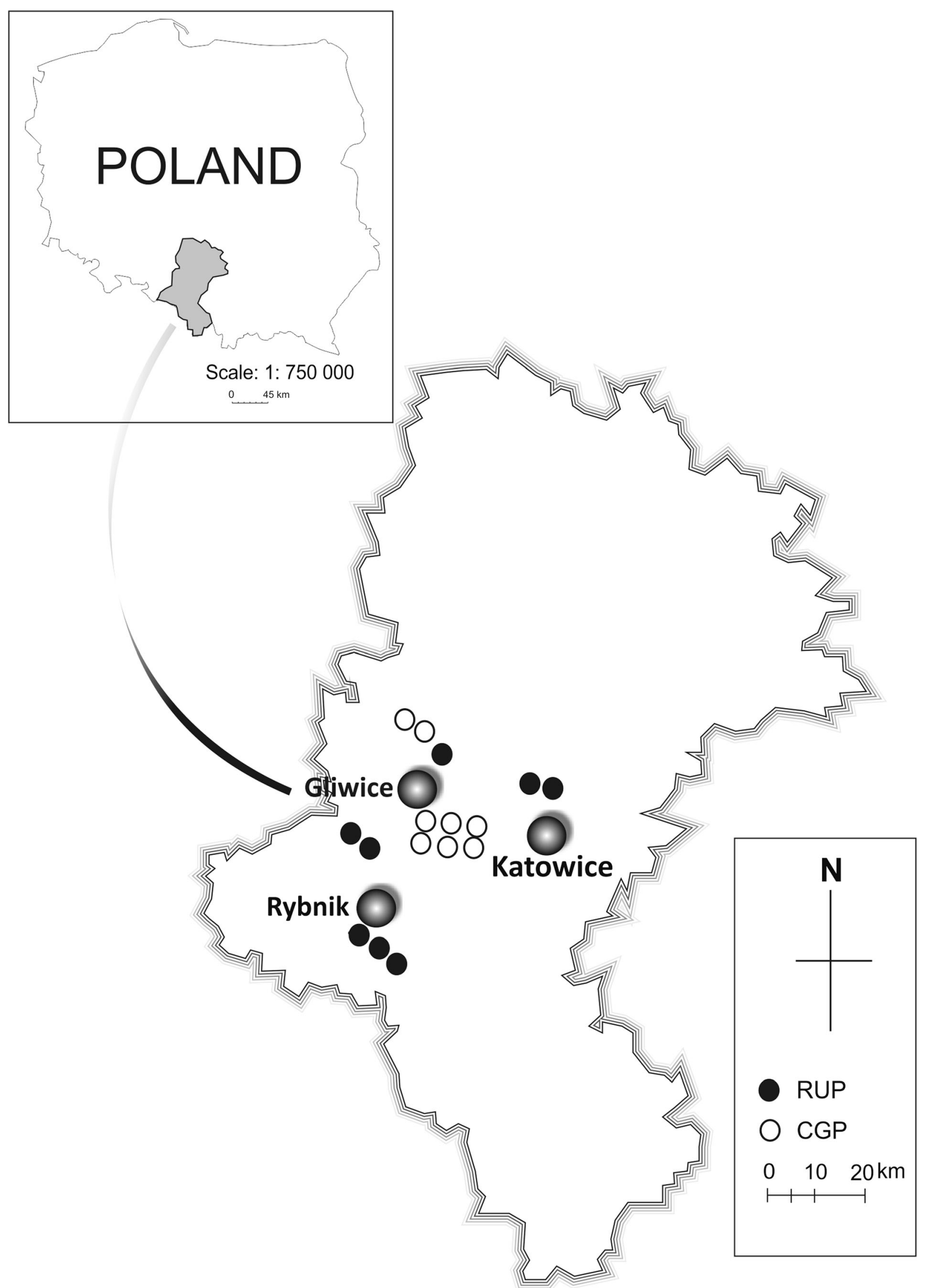

Fig. 1 Location of forest mining ponds in southern Poland. RUP - recreationally used ponds, CGP - control group of ponds 
cusidus (Linnaeus, 1758), Abramis brama (Linnaeus, 1758), Sander lucioperca (Linnaeus, 1758), Anguilla anguilla (Linnaeus, 1758), Esox lucius (Linnaeus, 1758) and Perca fluviatilis (Linnaeus, 1758). Water bodies that are known to have been used in recreation for at least several years were selected to this group. In the CGP, no artificial fish stocking activities are conducted (which does not preclude the presence of fish in a natural way), and they are not used for recreational purposes, probably because of their location deep in the forest interior where the use of vehicles of various types as well as unaccompanied walking is forbidden.

\section{Benthos sampling strategy and analysis}

The field part of this research was carried out in 2016 from June to September. The invertebrate samples were collected according to the quantitative quadrat method (Maqboul et al. 2014 ) by randomly placing a square frame $(0.25 \times 0.25 \mathrm{~m})$ into the bottom of ponds. Material was collected as eight subsamples (one frame each) in each pond (sampling area $0.5 \mathrm{~m}^{2}$ ) and include the substrate up to $20 \mathrm{~cm}$. This study was focused on the habitats that were both available and representative (leaf deposits, plants remains, bottom sediments). After transporting the collected material into the laboratory, the samples were washed using $0.02 \mathrm{~mm}$ mesh sieves and the benthic invertebrates were separated from the substrates. All invertebrates were fixed in $75 \%$ ethanol. The identification of organisms was carried out to the species (snails) and family level (most of the benthic groups).

Water samples for physical and chemical analysis were also collected (Dojlido 1999). We analysed temperature, $\mathrm{pH}$, total dissolved solids and conductivity in the field using a portable meter with electrode (HI 9811-5 pH/EC/ $\mathrm{TDS} /{ }^{\circ} \mathrm{C}$, Hanna Instruments, Woonsocket, RI, USA). After transporting the water samples to the laboratory in coolers, they were analysed for other parameters that are known to be important for the occurrence of benthos fauna, especially those for gastropods. Total hardness and the concentration of nitrates $\left(\mathrm{NO}_{3}\right)$, nitrites $\left(\mathrm{NO}_{2}\right)$, ammonia $\left(\mathrm{NH}_{4}\right)$, phosphates $\left(\mathrm{PO}_{4}\right)$, chlorides $(\mathrm{Cl})$, calcium $(\mathrm{Ca})$, and magnesium $(\mathrm{Mg})$ were measured in the laboratory using photometers and reagents by Hanna Instruments and Merck (Kenilworth, NJ, USA). The five classes of total hardness were adopted according to Hermanowicz et al. (1999).

Because water macrophytes constitute a food base for benthic invertebrates, the plants in each mining pond were identified and a list of the species composition of aquatic plants was created according to Szafer et al. (1986). The percentage of plant cover was visually estimated in each pond according to the Assessment Methodology (2015) scale: none = no plants, extremely sparse $>1 \%$, sparse $1-25 \%$ cover, moderate $>25-50 \%$ cover, dense $>50-75 \%$ cover, and very dense $>75$
$100 \%$. The coverage was assessed as the percentage of the pond area occupied by macrophytes.

\section{Zoocenological and statistical analysis}

The material analysis, with special emphasis on freshwater snails, included frequency (F) [\%] (Górny and Grüm 1981), - which was also calculated for the plants, and the dominance index (D) [\%] (Biesiadka and Kowalik 1980), classified as follows: $\mathrm{D}>10 \%$ eudominants; $\mathrm{D}=5.1 \%-10 \%$ dominants; $\mathrm{D}=2.0 \%-5.0 \%$ subdominants; $\mathrm{D}<2.0 \%$ recedents). The biodiversity indices, - the Shannon-Wiener index $\left(\mathrm{H}^{\prime}\right.$ - the natural logarithm base) and Simpson's diversity index (S) were calculated using the MVSP program version 3.13p (Kovach Computing Services). The relative abundance [\%] was expressed as the percentage composition of specific benthos taxa relative to the total number of collected specimens.

For the comparative analysis of macrophytes, the indexes of the Sørensen index: $Q S=2(A \cap B) /(A+B)$ and the Jaccard similarity coefficient: $\mathrm{J}(\mathrm{A}, \mathrm{B})=(\mathrm{A} \cap \mathrm{B})-[\mathrm{A}+\mathrm{B}-(\mathrm{A} \cap \mathrm{B})]$, were used (where $A$ and $B$ are the numbers of the elements in the two samples, $(A \cap B)$ - the number of the elements that are shared by both type of samples).

A model of direct gradient analysis was used to determine the influence of the environmental variables on the benthos assemblages and freshwater snails in the mining ponds. According to, ter Braak and Verdonschot (1995) and McCune (1997), this analysis also provide an integrated description of the species-environment relationships by assuming a common response (such as a unimodal distribution) of all of the species to a set of underlying environmental gradients. We used a detrended correspondence analysis (DCA) and the length of the gradient (4.0 SD for snails, $3.5 \mathrm{SD}$ for the analysis of benthic invertebrates). An unimodal ordination canonical correspondence analysis (CCA) with a forward selection was used to reduce the set of environmental variables. The significance of each variable was tested by manual selection using 1000 Monte Carlo permutations (CANOCO 4.5). The environmental variables that exhibited collinearity and the variance inflation factors (VIF) $>20$ were removed because such variables are strongly correlated with other variables (Palmer 1993). Based on the VIF, the following environmental variables were selected: water chemistry, the types of recreational use of the ponds, the depth of ponds, macrophyte species richness, and plant cover. The ordination diagram was constructed using CANODRAW (ver.4.5).

The Student's $t$ test was applied to compare the various characteristics of the benthic invertebrate assemblages, plant cover, and the parameters of the water among both groups of mining ponds (STATISTICA 12.0). A significance level of $p<0.05$ was specified for the statistical analyses. 


\section{Results}

\section{Water chemistry and aquatic plants}

RUP primarily varied in their salinity indicators i.e. - conductivity, total dissolved solids (TDS), and chloride content in the water compared to the CGP and these differences were statistically significant (Conductivity: $t=2.32, p<0.05$, TDS: $t=$ $2.59, p<0.05 ; \mathrm{Cl}: t=2.73, p<0.05)$. The maximum conductivity of $2892 \mu \mathrm{S} \mathrm{cm}^{-1}$ was found in the CGP. Although they also differ in the concentration of nitrates, the Student's $t$ test showed no statistical significance $(t=1.19, p=0.264)$. In the RUP, the content of nitrates in the water was $0-5 \mathrm{mg} \mathrm{dm}^{-3}$ and in the CGP $0.01-20 \mathrm{mg} \mathrm{dm}^{-3}$. The mean $\mathrm{pH}$ of the water was similar in both the CGP (7.6) and RUP (7.4). The hardness of the water in all of ponds was similar (mean values CGP:179 $\mathrm{mgCaCO}_{3} \mathrm{dm}^{-3}$, RUP $189 \mathrm{mgCaCO}_{3} \mathrm{dm}^{-3}$ ). The content of calcium (14-105 $\mathrm{mg} \mathrm{dm}^{-3}$ in the CGP and $15-123 \mathrm{mg} \mathrm{dm}^{-3}$ in the RUP), magnesium $\left(0.21-36.6 \mathrm{mg} \mathrm{dm}^{-3}\right.$ in the CGP, $3.2-29.5 \mathrm{mg} \mathrm{dm}^{-3}$ in the RUP), and nitrites (0.02$0.07 \mathrm{mg} \mathrm{dm}^{-3}$ in the CGP, $0.01-0.05 \mathrm{mg} \mathrm{dm}^{-3}$ in the RUP) was only slightly lower in the RUP compared to the CGP. The concentration of phosphates $\left(0.01-0.74 \mathrm{mg} \mathrm{dm}^{-3}\right.$ in the CGP, $0.01-1.2 \mathrm{mg} \mathrm{dm}^{-3}$ in the RUP) was slightly higher in the RUP compared to the CGP.

In both groups of ponds, 33 species of macrophytes were found ( 27 species in the RUP), but only 17 occurred in both groups (Table 1). The values of both similarity indices of the two groups of forest mining ponds were similar. Although the plant species richness was rather similar in the mining ponds of both groups, differences were visible in their plant cover $(t=3.11, p=0.0076)$. In the RUP, plants only occupied from $0.06-5.8 \%$ of the pond area, while in the CGP, they occupied from 13 to $75 \%$ of the pond area (Table 2).

\section{Benthic assemblages in the context of recreational use}

Although the invertebrate fauna appeared to be typical for anthropogenic water bodies, it markedly differed between the two treatments. We found the high densities of Oligochaeta, Hirudinea, Diptera, and Gastropoda in the CGP whereas, in the RUP, densities of Bivalvia, Trichoptera, Coleoptera and Odonata were higher (Table 3). Both Glossiphonidae and Erpobdellidae constitute the greater part of the leeches in the control group of ponds (Table 4). Benthos was more diverse in the RUP (Table 4), however its mean density showed huge differences between the treatments. It density amounted to 2629 ind. $\mathrm{m}^{-2}$ and only 755 ind. $\mathrm{m}^{-2}$ in the RUP $(t=2.991, p<0.05)$ (Table 4). Statistically different densities were also observed with Oligochaeta, Hirudinea, Odonata, Coleoptera, Trichoptera, Diptera and Gastropoda
Table 1 Composition and frequency (\% of ponds containing the species) of macrophyte species in the forest mining ponds

\begin{tabular}{|c|c|c|}
\hline Species & CGP & RUP \\
\hline Lysimachia thyrsiflora $\mathrm{L}$. & & 12.5 \\
\hline Lysimachia namularis & & 12.5 \\
\hline Lycopus europaeus L. & 50 & 50 \\
\hline Alisma plantago - aquatica $\mathrm{L}$. & 50 & 75 \\
\hline Eleocharis palustris (L.) Roem. \& Schult. & & 12.5 \\
\hline Phragmites australis(Cav.) Trin. ex. Steud & 87.5 & 87.5 \\
\hline Sparganium erectum L. em.Rchb. s.s. & 12.5 & 12.5 \\
\hline Batrachium aquatile $\mathrm{L}$. & 25 & \\
\hline Potamogeton natans $\mathrm{L}$. & 25 & 25 \\
\hline Ceratophyllumdemersum L. & 37.5 & 25 \\
\hline Elodea canadensis Michx. & 12.5 & \\
\hline Lemna minor $\mathrm{L}$. & & 37.5 \\
\hline Typha latifolia $\mathrm{L}$. & 87.5 & 100 \\
\hline Myriophyllum spicatum $\mathrm{L}$. & 12.5 & \\
\hline Galium palustre $\mathrm{L}$. & 12.5 & \\
\hline Glyceria maxima (Harth.) Holmb & 75 & 50 \\
\hline Heleocharis palustris (L.) Roem. \& Schult & 37.5 & 37.5 \\
\hline Schoenoplectus lacustris (L.) Palla & 25 & 25 \\
\hline Utricularia vulgaris L. & 12.5 & 12.5 \\
\hline Bidens tripartitus L. & 62.5 & 50 \\
\hline Oenanthe aquatica (L.) & 50 & 25 \\
\hline Peucedanum palustre (L.) & 25 & 12.5 \\
\hline Sparganium erectum L. em. Rchb. s.s. & 37.5 & 25 \\
\hline Equisetum fluviatile L. & 37.5 & \\
\hline Iris pseudoacorus L. & 37.5 & 37,5 \\
\hline Polygonum amfibium $\mathrm{L}$ & 12.5 & 12,5 \\
\hline Potamogeton crispus L & 12.5 & \\
\hline Acorus calamus L. & & 37.5 \\
\hline Cirsium palustre L. Scop. & & 12.5 \\
\hline Phalari sarundinacea $\mathrm{L}$. & & 12.5 \\
\hline Utricularia vulgaris L. & & 12.5 \\
\hline Rumex hydrolapathum Huds. & 25 & 25 \\
\hline Hottonia palustris $\mathrm{L}$. & & 25 \\
\hline Number of species & 24 & 27 \\
\hline Number of species in both types & 17 & \\
\hline Sørensen index & 0.67 & \\
\hline Jaccard index & 0.5 & \\
\hline
\end{tabular}

$R U P$ recreationally used ponds, $C G P$ control group of ponds

(Table 3). The differences between the number of specimens of gastropods and other benthic invertebrates were much greater in the CGP (Fig. 2).

The model of the CCA was statistically significant (Monte Carlo: the first canonical axis, F-ratio $=1.153$, $p=0.032$; all canonical axes, F-ratio $=1.613, p=0.001$ ), and showed association of some groups of benthic invertebrates with the plant cover and ponds in which 
Table 2 Type of recreation and plant cover [\%] in the forest mining ponds

\begin{tabular}{lllll}
\hline Type of recreation & CGP & RUP & N \\
& & & \\
Wild fisheries & - & & + & 8 \\
Recreational angling & - & + & 8 \\
Swimming & - & & + & 6 \\
Power boating & - & & + & 4 \\
Canoeing & - & & + & 2 \\
Feeding birds & - & & + & 8 \\
Plant cover & Plant cover [\%] & $\mathrm{N}$ & Plant cover [\%] & $\mathrm{N}$ \\
Dence & 75.2 & 1 & - & 0 \\
Moderate & $25.3-25.9$ & 2 & - & 0 \\
Sparse & $13-16.8$ & 5 & $1-5.8$ & 4 \\
Extremely Sparce & - & 0 & $0.06-0.9$ & 4 \\
\hline
\end{tabular}

$R U P$ recreationally used ponds, $C G P$ control group of ponds, $N$ number of ponds

recreational angling was not permitted (e.g., Oligochaeta, Chioronomidae, Ceratopogonidae, Asellidae) (Fig. 3). Limonidae, Stratiomyidae, Elmidae and Leptoceridae were

Table 3 Mean densities (number per $\mathrm{m}^{-2}$ ) of the invertebrate taxa found in both group of ponds studied

\begin{tabular}{llll}
\hline & $\begin{array}{l}\text { Total } \\
(N=16)\end{array}$ & $\begin{array}{l}\text { CGP } \\
(N=8)\end{array}$ & $\begin{array}{l}\text { RUP } \\
(N=8)\end{array}$ \\
\hline $\begin{array}{lll}\text { Oligochaeta* } \\
(t=2.41)\end{array}$ & $\begin{array}{l}226.5 \pm 295.4 \\
(0-968.0)\end{array}$ & $\begin{array}{l}327.5 \pm 384.2 \\
(0-968.0)\end{array}$ & $\begin{array}{l}125.5 \pm 126.9 \\
(0-367.0)\end{array}$ \\
Hirudinea* & $53.3 \pm 84.1$ & $99.6 \pm 100.4$ & $7.0 \pm 12.9$ \\
$(t=2.59)$ & $(0-219.0)$ & $(0-219.0)$ & $(0-36.0)$ \\
Crustacea & $2.6 \pm 3.8$ & $2.4 \pm 3.3$ & $2.7 \pm 4.4$ \\
& $(0-12.0)$ & $(0-9.0)$ & $(0-12.0)$ \\
Odonata* & $18.3 \pm 51.5$ & $2.4 \pm 4.5$ & $34.2 \pm 71.2$ \\
$(t=-3.26)$ & $(0-201.0)$ & $(0-11.0)$ & $(0-201)$ \\
Ephemeroptera & $24.1 \pm 59.1$ & $26.6 \pm 70.1$ & $21.6 \pm 50.6$ \\
& $(0-200.0)$ & $(0-200.0)$ & $(0-146.0)$ \\
Megaloptera & $3.0 \pm 6.1$ & $4.5 \pm 7.7$ & $1.5 \pm 3.8$ \\
& $(0-22.0)$ & $(0-22.0)$ & $(0-11.0)$ \\
Coleoptera* & $63.2 \pm 137.5$ & $41.1 \pm 55.4$ & $85.4 \pm 190.6$ \\
$(t=-2.63)$ & $(0-554.0)$ & $(0-128.0)$ & $(0-554.0)$ \\
Trichoptera & $8.81 \pm 14.9$ & $3.0 \pm 7.7$ & $14.6 \pm 18.4$ \\
& $(0-48.0)$ & $(0-22.0)$ & $(0-48.0)$ \\
Heteroptera & $6.2 \pm 8.5$ & $7.87 \pm 9.1$ & $4.50 \pm 8.0$ \\
& $(0-22.0)$ & $(0-22.0)$ & $(0-22.0)$ \\
Diptera* & $892.4 \pm 1357.6$ & $1488.5 \pm 1754.7$ & $296.4 \pm 241.7$ \\
$(t=2.90)$ & $(11-4176.0)$ & $(16.0-4176.0)$ & $(11.0-726.0)$ \\
Gastropoda* & $390.1 \pm 505.5$ & $626.7 \pm 632.4$ & $153.4 \pm 140.3$ \\
$(t=2.87)$ & $(0-1744.0)$ & $(0-1744.0)$ & $(0-394.0)$ \\
Bivalvia & $3.5 \pm 14.0$ & 0.0 & $7.04 \pm 19.8$ \\
& $(0-56.0)$ & & $(0-56.0)$ \\
\hline
\end{tabular}

Means are given as $\pm 1 \mathrm{SE}$ (Standard error), range in parentheses $R U P$ recreationally used ponds, $C G P$ control group of ponds

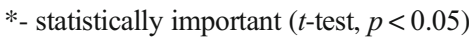

Table 4 Taxa richness and frequency index of the benthic invertebrates in the forest mining ponds

\begin{tabular}{|c|c|c|c|c|c|}
\hline & & \multicolumn{2}{|l|}{ CGP } & \multicolumn{2}{|l|}{ RUP } \\
\hline & & $\mathrm{A}$ & $\mathrm{F} \%$ & $\mathrm{~A}$ & $\mathrm{~F} \%$ \\
\hline & Oligochaeta & 12.45 & 87.5 & 16.74 & 75 \\
\hline \multirow[t]{3}{*}{ Hirudinea } & Glossiphoniidae & 2.36 & 50 & 0.78 & 25 \\
\hline & Erpobdellidae & 1.42 & 50 & 0.15 & 37.5 \\
\hline & Asellidae & 0.09 & 50 & 0.36 & 37.5 \\
\hline \multirow[t]{5}{*}{ Odonata } & Lestidae & 0 & 0 & 1.06 & 25 \\
\hline & Coenagrionidae & 0 & 0 & 0.25 & 25 \\
\hline & Platycnemidae & 0 & 0 & 0 & 25 \\
\hline & Corduliidae & 0 & 0 & 0.18 & 12.5 \\
\hline & Libellulidae & 0.09 & 25 & 2.99 & 12.5 \\
\hline \multirow[t]{3}{*}{ Ephemeroptera } & Ephemerellidae & 0.05 & 12.5 & 0 & 0 \\
\hline & Baetidae & 0.04 & 12.5 & 0 & 0 \\
\hline & Caenidae & 0.92 & 25 & 2.87 & 37.5 \\
\hline Megaloptera & Sialidae & 0.17 & 50 & 0.2 & 25 \\
\hline \multirow[t]{5}{*}{ Coleoptera } & Haliplidae & 0.04 & 12.5 & 0.23 & 12.5 \\
\hline & Dytiscidae & 0.46 & 62.5 & 4.98 & 25 \\
\hline & Helodidae & 0 & 0 & 4.11 & 12.5 \\
\hline & Elmidae & 0 & 0 & 0,8 & 12.5 \\
\hline & Hydrophilidae & 1.07 & 75 & 1.21 & 62.5 \\
\hline \multirow[t]{4}{*}{ Trichoptera } & Leptoceridae & 0 & 0 & 1.34 & 25 \\
\hline & Phryganeidae & 0.005 & 12.5 & 0 & 0 \\
\hline & Polycentropodidae & 0.05 & 12.5 & 0.4 & 12.5 \\
\hline & Ecnomidae & 0.06 & 25 & 0.2 & 25 \\
\hline \multirow[t]{2}{*}{ Heteroptera } & Corixidae & 0.1 & 12.5 & 0.36 & 12.5 \\
\hline & Naucoridae & 0.19 & 37.5 & 0.23 & 25 \\
\hline \multirow[t]{7}{*}{ Diptera } & Chironomidae & 56 & 100 & 32.25 & 100 \\
\hline & Ceratopogonidae & 0.57 & 37.5 & 2.59 & 62.5 \\
\hline & Limoniidae & 0 & 0 & 0.28 & 25 \\
\hline & Tabanidae & 0.03 & 25 & 0.55 & 25 \\
\hline & Stratiomyiidae & 0 & 0 & 0.28 & 25 \\
\hline & Tipulidae & 0 & 0 & 1.03 & 25 \\
\hline & Ptychopteridae & 0 & 0 & 2.36 & 12.5 \\
\hline \multirow[t]{4}{*}{ Gastropoda } & Lymnaeidae & 4.12 & 75 & 6.62 & 50 \\
\hline & Planorbidae & 3.09 & 75 & 11.61 & 87.5 \\
\hline & Hydrobiidae & 0.08 & 12.5 & 1.48 & 37.5 \\
\hline & Physidae & 16.54 & 37.5 & 0.75 & 12.5 \\
\hline Bivalvia & Sphaeriidae & 0 & 0 & 0.93 & 12.5 \\
\hline \multicolumn{2}{|l|}{ Taxa richness } & 24 & & 32 & \\
\hline \multicolumn{2}{|c|}{ Number of taxa in both pond types } & 21 & & & \\
\hline \multicolumn{2}{|l|}{ Mean density } & 2629 & 755 & & \\
\hline
\end{tabular}

A [\%] relative abundance, $F \%$ frequency index, CGP Control group ponds, $R U P$ Recreationally use ponds

associated with low values of conductivity. Density and diversity of benthic invertebrates was observed to differ in relation to the kind of recreational use involved (recreational angling, swimming, power boating) (Fig. 3). 
Fig. 2 Number of specimens of gastropods and other groups of benthic invertebrates in the forest mining ponds, Ind. col. Individuals collected. Benthos other groups of invertebrates except with the snails. RUP recreationally used ponds, CGP control group of ponds

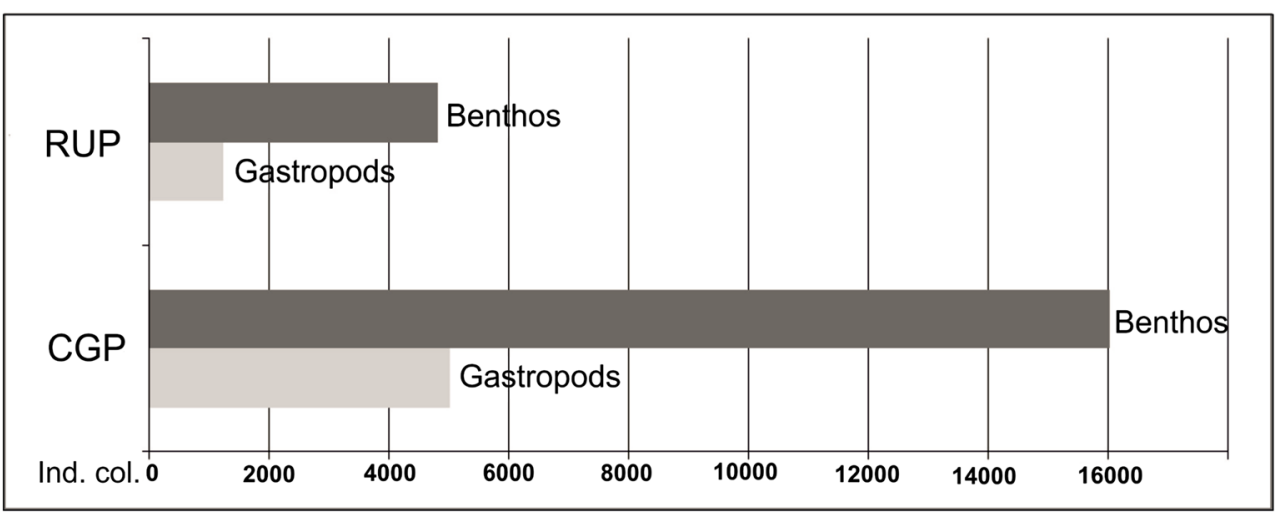

\section{Freshwater snail assemblages in the context of recreational use}

The relative abundance of most of the species of snails (Anisus vortex, Physa fontinalis, Physella acuta, Aplexa hypnorum,
Anisus spirorbis, Gyraulus crista, Ferrissia fragilis, Planorbarius corneus, Stagnicola palustris, Lymnaea stagnalis, and Radix auricularia) was higher in the CGP than in the RUP. Only G. albus constituted $50 \%$ of the snails collected in both groups of mining ponds (Fig. 4).

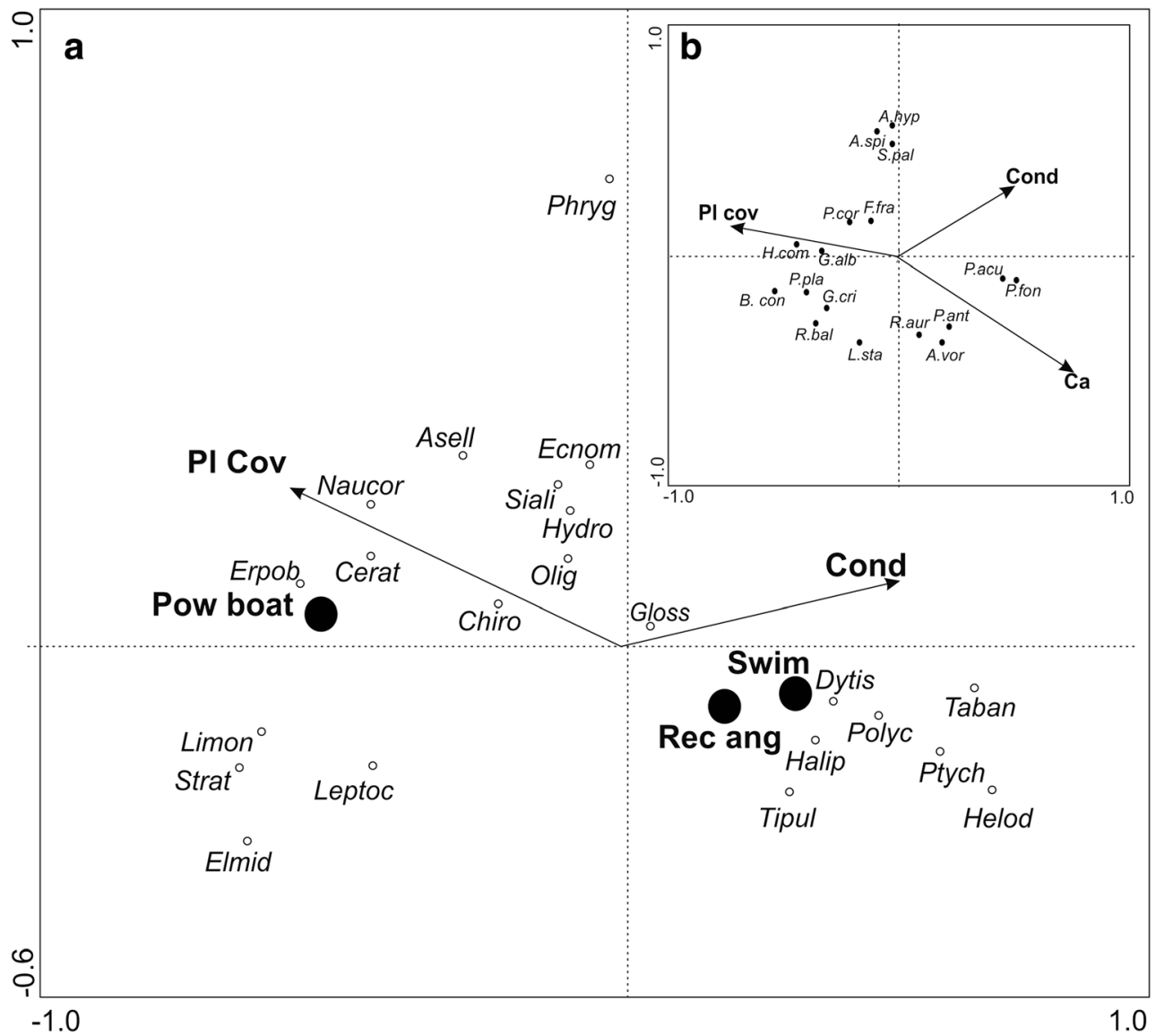

Fig. 3 Ordination diagram for the benthos assemblages (a), freshwater snails (b) and environmental variables. Variables abbreviations: Pl covplant cover, Pow boat- power boating, Swim- swimming, Rec ang,- recreational angling, Cond- conductivity, Ca- calcium content, PtychPtychopteridae, Phryg -Phryganeidae, Hydro- Hydrophilidae, TipulTipulidae, Taban- Tabanidae, Halip- Haliplidae, CeratCeratopogonidae, Dytis- Dytiscidae, Ecnom- Ecknomidae, ErpobErpobdellidae, Gloss - Glossiphonidae, Naucor- Naucoridae, AsellAsellidae, Helod- Helodidae, Olig- Oligochaeta, Chiro- Chironomidae,
Polyc- Polycentropodidae, Leptoc- Leptoceridae, Elmid- Elmidae, StratStratiomyidae, Siali- Sialidae, Limon- Limonidae, P.pla- Planorbis planorbis, R. balt-Radix balthica, G.alb-Gyraulus albus, L.staLymnaea stagnalis, B.con- Bathyomphalus contortus, H.com- Hippeutis complanatus, F.fra- Ferrissia fragilis, P.cor-Planorbarius corneus, P.fon- Physa fontinalis, A.spi- Anisus spirorbis, G.cri- Gyraulus crista, R.aur-Radix auricularia, P.acu- Physella acuta. P.ant-Potamopyrgus antipodarum, S.pal- Stagnicola palustris, A.vor-Anisus vortex, A.hypAplexa hypnorum 
Fig. 4 Relative abundance of freshwater snails in the forest mining ponds. RUP recreationally used ponds, CGP control group of ponds

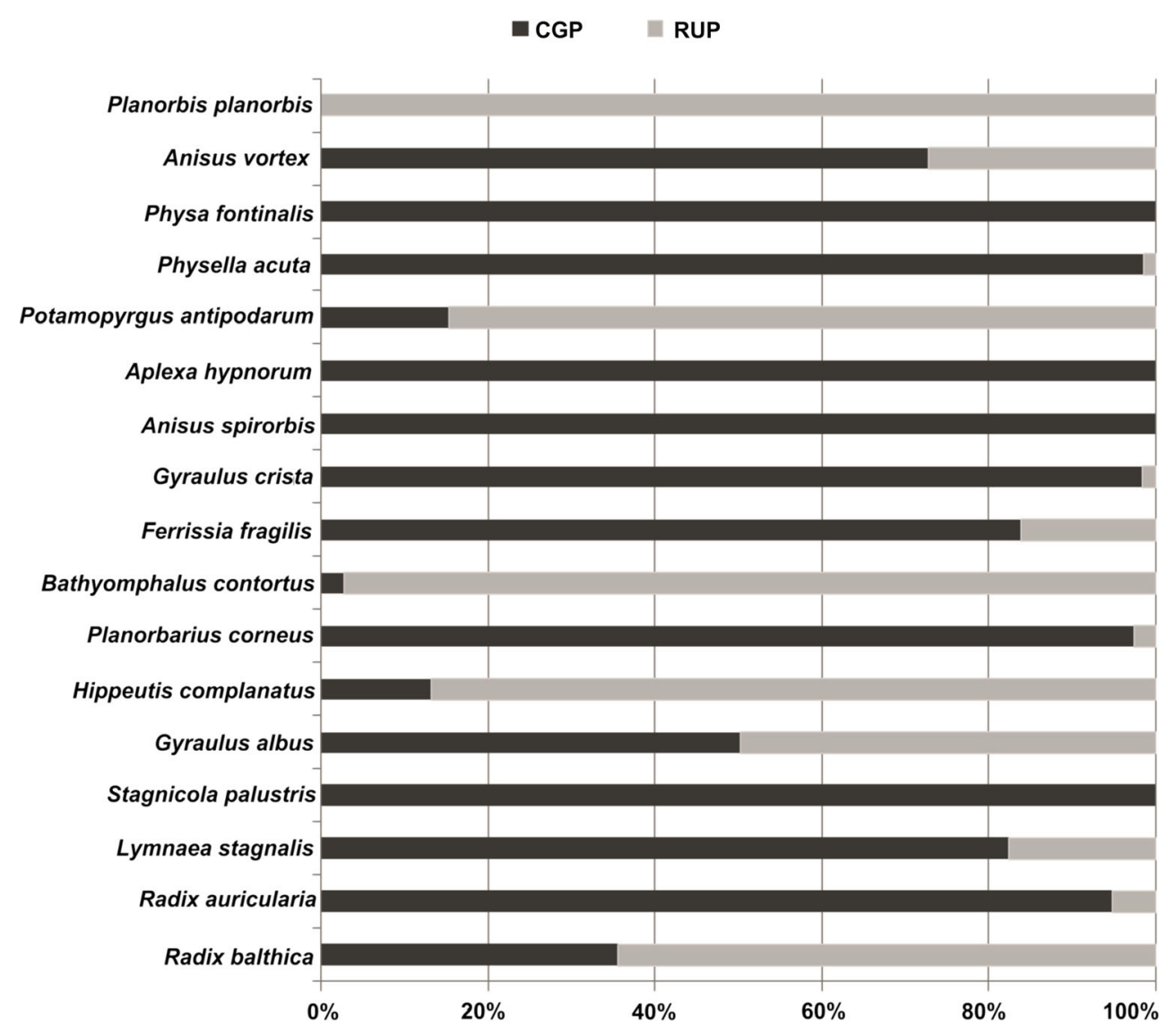

The control group of ponds was characterised by a greater number of snail species and the total number of individuals collected compared to the RUP (Table 5). The densities of snails were higher in the CGP (mean: 625 ind. $\mathrm{m}^{-2}$, maximum: 1088 ind. $\mathrm{m}^{-2}$ ) compared to the RUP (mean: 153 ind. $\mathrm{m}^{-2}$, maximum: 394 ind. $\left.\mathrm{m}^{-2}\right)(t=2.970, p<0.05)$. The values of the diversity indices were slightly higher in the control group, however when calculated by types, their value showed a very low diversity in the RUP (Table 5). The dominance patterns of the snail assemblages were completely different in both groups of ponds. In the RUP four species were classified as Eudominants whereas in the CGP, two species belonged to the eudominants and only one dominant species was found ( $P$. fontinalis) (Table 5).

All above mentioned differences between treatments (RUP vs CUP) and snails occurrence are most likely connected with the macrophyte abundance as plant cover was greatly reduced in recreational ponds, although plant diversity was enhanced. This strong relationship was documented by the statistically significant results of forward selection. In the group of snails associated with the plant cover and lower values of conductivity, among others, belonged the following: Bathyomphalus contortus, Planorbis planorbis, Radix balthica and Gyraulus albus (Fig. 3). Despite the fact that the content of Ca was only slightly lower in the RUP statistical analysis linked the occurrence of a few species of snails with its concentration in the water. The model of ordination analysis was statistically significant (Monte Carlo: the first canonical axis F-ratio = $0.291, p=0.011$; all canonical axes F-ratio $=1.374, p=0.001$ ).

\section{Discussion}

The variety of environment responses to disturbances is one of the greatest challenges in attempting to deal with the coexistence of fauna and flora with recreation (Hadwen et al. 2003; Pickering and Castley 2011). Recreation to the shoreline and bottom affects plants, leaf deposits, and consequently the invertebrates (De Meester et al. 2005).

Plants in recreational habitats are less abundant (reduced density, cover), with a species composition that is different compare to undisturbed areas (Cole and Bayfield 1993; Gutzwiller 2013). This was confirmed in our research as plant cover was greatly reduced in recreational ponds, although plant diversity was enhanced. It is likely that reducing macrophytes resulted from using power boating (cutting off macrophyte) or swimming activity. Although the implications of the recreational impact depends on the intensity of disturbance, their diversity can increase at low to moderate levels due to increases in the spatial heterogeneity, and species richness 
Table 5 Freshwater snails in the forest mining ponds

\begin{tabular}{|c|c|c|c|c|}
\hline \multirow[b]{2}{*}{ Taxon } & \multicolumn{2}{|l|}{ CGP } & \multicolumn{2}{|l|}{ RUP } \\
\hline & Dominance & Frequency & Dominance & Frequency \\
\hline Radix balthica (L., 1758) & 3.8 & 62.5 & 28.1 & 37.5 \\
\hline Radix auricularia (L., 1758) & 11.6 & 50.0 & 2.6 & 12.5 \\
\hline Lymnaea stagnalis (L., 1758) & 1.6 & 12.5 & 1.4 & 25.0 \\
\hline Stagnicola palustris (O.F. Müller, 1774) & 0.3 & 25.0 & 0.0 & 0.0 \\
\hline Gyraulus albus (O.F. Müller, 1774) & 2.5 & 25.0 & 10.2 & 62.5 \\
\hline Hipeutis complanatus (L., 1758) & 0.9 & 12.5 & 23.3 & 37.5 \\
\hline Planorbarius corneus (L., 1758) & 3.8 & 62.5 & 0.4 & 12.5 \\
\hline Bathyomphalus contortus (L., 1758) & 0.1 & 12.5 & 14.4 & 12.5 \\
\hline Ferrissia fragilis (Tryon, 1863) & 0.4 & 37.5 & 0.4 & 25.0 \\
\hline Gyraulus crista (L., 1758) & 3.7 & 62.5 & 0.2 & 12.5 \\
\hline Anisus spirorbis (L., 1758) & 1.2 & 12.5 & 0.0 & 0.0 \\
\hline Aplexa hypnorum (L., 1758) & 0.2 & 12.5 & 0.0 & 0.0 \\
\hline Potamopyrgus antipodarum (Gray, 1843) & 0.3 & 12.5 & 6.9 & 37.5 \\
\hline Physella acuta (Draparnaud, 1805) & 63.2 & 37.5 & 3.7 & 12.5 \\
\hline Physa fontinalis (L., 1758) & 6.1 & 12.5 & 0.0 & 0.0 \\
\hline Anisus vortex (L., 1758) & 0.3 & 12.5 & 0.5 & 12.5 \\
\hline Planorbis planorbis (L., 1758) & 0.0 & 0.0 & 7.9 & 12.5 \\
\hline Number of species in total & 16 & & 13 & \\
\hline Number of species per pond (range) & $0-7$ & & $0-4$ & \\
\hline Density (ind. $\mathrm{m}^{-2}$ ) per pond & $0-1088$ & & $0-394$ & \\
\hline Density (ind. $\mathrm{m}^{-2}$ ) (mean) & 626 & & 153 & \\
\hline Simpson diversity index per pond & $0-0.89$ & & $0-0.79$ & \\
\hline Simpson diversity index in total & 0.42 & & 0.18 & \\
\hline Shannon-Wiener diversity index per pond & $0-1.55$ & & $0-1.11$ & \\
\hline
\end{tabular}

Dominance and Frequency in [\%], RUP recreationally used ponds, $C G P$ control group of ponds
(Taylor and Erman 1979; Cole and Landers 2013). According to our investigation, the occurrence of snails was mainly associated with plant cover. In forest ponds, the higher percentage of organic matter comes from the surrounding forest, which provides decomposing material in the form of leaf deposits (Spyra 2017; Spyra 2018), which is the main habitat for benthic invertebrates. We can, therefore, suspect that recreation, which alters the structure of leaf deposits by trampling them, may substantially change the assemblages of invertebrates.

Despite the fact that shore-based recreational activities are known to change water chemistry, e.g., by contributing nutrient influxes (Cole and Landers 2013), small aquatic water bodies are susceptible to the influence of anthropogenic pressure, e.g., to water pollution (Collinson et al. 1995; Jeffries 2011), especially when they are located in industrial areas. The small size of mining ponds results in more frequent changes in their physico-chemical properties compared to the other types of anthropogenic water bodies (Růžičková et al. 2014). The differences in the water chemistry of the mining ponds were primarily connected with the salinity indicators, which are known to influence the occurrence of freshwater snails. It is, in fact, difficult to determine whether they were the result of the recreational use of ponds, since we did not find more significant differences in the chemistry of the waters beyond those mentioned above. In the CCA analysis, only three environmental factors were indicated to be statistically important in explaining a significant proportion of the variance in the snail assemblages. Conductivity had an influence on both the benthic invertebrates and snails. Despite only slight differences in $\mathrm{Ca}$ concentration between the treatments (RUP vs CUP) CCA linked the occurrence of a few species also with the $\mathrm{Ca}$ its content in the water. In the CGP, snails were more abundant and diverse than in the RUP. The differences were clearly visible in their dominance patterns and density, which were higher in the CGP (mean: 625 ind. $\mathrm{m}^{-2}$ ) compared to the RUP (mean: 153 ind. $\mathrm{m}^{2}$ ). It seems that this differences was most strongly related with the macrophyte abundance.

Because the RUP are used for recreational angling, it can be speculated that the presence of fish may greatly impact the diversity of snail assemblages and other benthic invertebrates. 
It is important is to distinguish commercial fishing (intensive fish products for sale) from the wild fisheries (for sport and leisure, personal consumption) (Cooke and Cowx 2006) like mining ponds of this study. It can be hypothesized that, only in regularly stocked water bodies or in the experimental studies in which fish populations are large, do fish negatively impact the benthos fauna; however, we speculate that this is also probably possible in wild-stocked environments used as wild fisheries. Ponds that have no fish - have abundant insect populations therefore, we attempted to determine how the snail assemblages differed in the two groups of ponds. It is likely that obtained differences may be linked with the molluscivorous fish, which predate on snails, regulate and can reduce their densities (Brönmark and Pettersson 1994; Turner and Chislock 2007; Saddozai et al. 2013). The presence of pharyngeal teeth, which can crush shells, helps them to feed on snails (Lakowitz et al. 2008), and are typical to cyprinid fish, which occur in the wild-stocked ponds in this study e.g. Cyprinus carpio, Abramis brama and Leucis cusidus. Theerefore, the results of our study are consistent with the opinion of Hubendick (1958) that it is sometimes difficult to distinguish the importance of a single basic factor that influences the occurrence of snails. Constant elements of the snail fauna in the mining ponds were species that have a wide range of ecological tolerances. The small constancy in the occurrence of some species in both groups of ponds, regardless of the recreational use, also shows that their presence depends more on the physico-chemical properties of water and plant cover.

Our study also showed a less numerous occurrence of benthos in the ponds used for recreational angling. Oligochaeta, Hirudinea, Diptera and Gastropoda occurred numerously in the CGP, whereas in the RUP we found the most numerous occurrence of Bivalvia, Trichoptera, as well as large invertebrate predators Coleoptera and Odonata. We can speculate that this probably might also be connected with the use of ponds for fishing. The activities of benthovorous fish cause the re-suspension of bottom sediments, thus increasing the periphyton biomass, which has a negative impact on the abundance of invertebrates (Crowder and Cooper 1979; Brönmark et al. 1992; Persson and Svensson 2006). In contrast, Rennie and Jackson (2005) found an increasing invertebrate density in water bodies with fish in a situation in which there was an increasing microhabitat complexity. According to Gilinsky (1984), fish predation has a significant impact on both the number of benthic species and their densities, because invertebrates provide a fish food source that contains high amounts of protein, and is rich in amino acids (Epler et al. 2010). Benthic fauna in sites without the fish presence (Resh and Rosenberg 1993) are represented by three main groups - chironomids, snails, and oligochaetes (Pamplin et al. 2006). However, in the CGP, similar to oligochaetes, chironomids were the most numerous compared to the RUP in which they are probably eaten by fish as the preferred food types of cyprinid fish (Uzunov et al. 1988).
In aquatic environments, different types of stress related with recreation (commercial fishing, pollutant discharges, deforestation, habitat alteration, waves created by boats, swimming) often influence benthos, mainly the number of individuals and species abundance (Anderson 2013; Gutzwiller 2013), alter some characteristic of environments, e.g., shelters and living-space (Monz et al. 2013). This was confirmed in our study in relation to invertebrates in the context of power boating, swimming (bathing) and recreational angling. Recreational activities that alter the substrates of benthos occurrence such as leaf deposits and plants, consequently will have a large impact on aquatic organisms. Moreover, the use of motor boats (wash, turbulence and turbidity) is also important. Gabel et al. (2012) found that the shear stress associated with wave trains from the use of boats in recreation at a distance of $35 \mathrm{~m}$ from the shore resulted in a $45 \%$ detachment of littoral invertebrates, and, at distance of $20 \mathrm{~m}$, invertebrate detachment was up to $75 \%$. In small mining ponds, the effect of using boats would also probably be significant and would likely influence the benthos communities.

Forest mining ponds whose origin is related to human activity remain under the influence of recreationists. According to our results, angling and recreational activity, such as swimming and motor boating, can be seen as intentional interaction with environments, and other types of recreation have a rather accidental impact. Our study showed that anthropogenic habitat use in recreation affects invertebrates. More diverse and abundant gastropod fauna in ponds not used for recreation appeared to relate strongly to plant cover as cover was greatly reduced in recreational ponds, although plant diversity was enhanced. Density and diversity of benthic invertebrates was also observed to differ in relation to the kind of recreational use involved (recreational angling, swimming, power boating) although this was not quantified. The occurrence of freshwater snails primarily depended on the $\mathrm{Ca}$ concentration, conductivity of the water and plant cover, but recreational disturbance appeared to reduce abundance where it occurred and was related to a reduction in overall plant cover.

The recreation industry and its management face significant challenges in promoting sustainable development and using natural ecosystems for recreational purposes in helping to support areas by implementing management practises to reduce the impacts on fauna and flora. According to Gutzwiller (2013) and HaySmith and Hunt (2013), animals are more likely to persist in a habitat if its modification by recreationists is minimized. The species abundance depends partly on specific habitat features and when recreational activities alter the environmental conditions, and these community attributes can change (Gutzwiller 2013). Integrated recreation ecology management has a huge potential to form the basis for the management approaches of freshwaters (Venohr et al. 2018), and this is the reason for the importance of understanding the impact of anthropogenic habitat use on the ecosystem. Our study represent a preliminary results on how the recreational use of mining ponds may regulate invertebrate 
abundance. To show whether they may also play an important role in diversifying the ecological function of benthos assemblages across various complex habitats and different environmental factors in water bodies both natural and anthropogenic the further long term study are needed.

Acknowledgments Authors would like to thank the University of Silesia for founding support of this research and to Ms. Michele L. Simmons, BA from the English Language Centre (ELC), and to Mr. Gerard Nawrocki, Letterman Sp. z o.o., Kraków, Poland, for final corrections and improving the English style of the manuscript.

Funding This study was funded by the University of Silesia.

\section{Compliance with ethical standards}

Conflict of interest The authors declare that they have no conflict of interest.

Ethical approval All of the experiments complied with the current Polish law.

Open Access This article is distributed under the terms of the Creative Commons Attribution 4.0 International License (http:// creativecommons.org/licenses/by/4.0/), which permits unrestricted use, distribution, and reproduction in any medium, provided you give appropriate credit to the original author(s) and the source, provide a link to the Creative Commons license, and indicate if changes were made.

\section{References}

Anderson SH (2013) Recreational disturbance and wildlife populations. In: Knight RI, Gutzwiller KJ (eds) Wildlife and recreationists: coexistence through management and research. Island Press, Washington, pp 157-168

Assessment Methodology (2015) Lakes assessment methods. Assessment and listing methodology for integrated water quality monitoring and assessment reporting. Bureau of clean water. Aquatic macrophyte coverage procedures for lake assessment. Pennsylvania Department of Environmental Protection. https:// www.dep.pa.gov/Business/Water/CleanWater/WaterQuality/Pages/ Assessment-Methodology.aspx. Accessed 12 Feb 2019

Biesiadka E, Kowalik W (1980) Water mites (Hydracarina) of Western Bieszczady Mountains. 1. Stagnant waters. Acta Hydrobiol 3:279-298

Biggs J, Corfield A, Walker D, Whitfield M, Williams P (1994) New approaches to the management of ponds. British Wildlife 5:273-287

Brönmark C, Malmqvist B (1986) Interactions between the leech Glossiphonia complanata and its gastropod prey. Oecologia 69: 268-227. https://doi.org/10.1007/BF00377633

Brönmark C, Pettersson LB (1994) Chemical cues from piscivores induce a change in morphology in crucian carp. Oikos 70:396-340. https:// doi.org/10.2307/3545777

Brönmark C, Klosiewski SP, Stein RA (1992) Indirect effects of predation in a freshwater benthic food chain. Ecology 73:1662-1674

Brown KM, Aleksander JE, Thorp JH (1998) Differences in the ecology and distribution of lotic Pulmonate and Prosobranch gastropods. Am Malacol Bull 14:91-101

Céréghino R, Boix D, Cauchie H-M, Martens K, Oertli B (2014) The ecological role of ponds in a changing world. Hydrobiologia 723:16. https://doi.org/10.1007/s10750-013-1719-y
Cole DN, Bayfield NG (1993) Recreational trampling of vegetation: standard experimental procedures. Biol Conserv 63:209-215. https://doi.org/10.1016/0006-3207(93)90714-C

Cole DN, Landers PB (2013) Indirect effects of recreation on wildlife. In: Knight RI, Gutzwiller KJ (eds) Wildlife and recreationists: coexistence through management and research. Island Press, Washington, pp 183-202

Collinson NH, Biggs J, Corfield MJ, Hodson D, Walkert D, Whitifield M, Willimas PJ (1995) Temporary and permanent ponds: an assessment of the effects of drying out on the conservation value of aquatic macroinvertebrate communities. Biol Conserv 74:125-133. https:// doi.org/10.1016/0006-3207(95)00021-U

Cooke SJ, Cowx IG (2006) Contrasting recreational and commercial fishing: searching for common issues to promote unified conservation of fisheries resources and aquatic environments. Biol conserv 128(1):93-108

Crowder LB, Cooper WE (1979) Structural complexity and fish-prey interactions in ponds: a point of view. In: Johnson DL, Stein RA (eds) Response of fish to habitat structure in standing water. North Central Division, American Fisheries Society, Special Publication 6, pp 2-10

Dąbrowska D, Dąbrowski J (2015) Change the number of water reservoirs in the selected cities of the upper Silesian agglomeration over the period 1993-2014. Environ Socio-econ Stud 3:23-29. https:// doi.org/10.1515/environ-2015-0059

Dabrowska D, Soltysiak M (2015) The impact of anthropogenic factors on the natural values of the water reservoirs in Sosnowiec. Environ Socioecon Stud 3:20-25. https://doi.org/10.1515/environ-2015-0053

De Meester L, Declerck S, Stoks R, Louette G, van de Meutter F, de Bie T, Michels E, Brendonck L (2005) Pond and pools as model systems in conservation biology, ecology and evolutionary biology. Aquat Conserv Mar Freshwat Ecosyst 15:715-725. https://doi.org/10. $1002 /$ aqc. 748

Dojlido J (1999) Chemia wód powierzchniowych. Wydawnictwo Ekonomia i Środowisko, Białystok

Epler P, Borowiec F, Sokołowska-Mikołajczyk M, Fałowska B (2010) Content of basic nutrients, amino acids and fatty acid in the benthos of carp ponds. AACL Bioflux 3:125-131

Gabel F, Garcia XF, Schnauder I, Pusch MT (2012) Effects of shipinduced waves on littoral benthic invertebrates. Freshw Biol 57(12):2425-2435. https://doi.org/10.1111/fwb.12011

Gilinsky E (1984) The role of fish predation and spatial heterogeneity in determining benthic community structure. Ecology 65(2):455-468

Górny M, Grüm L (1981) Metody stosowane w zoologii gleby. Państwowe Wydawnictwo Naukowe, Poland, Warszawa, Warszawa

Grochowska J, Tandyrak R, Dunalska J, Górniak D (2004) Drainage basin impacts of the hydrochemical condoction in small water reservoirs of the eastern periferies of Olsztyn. Limnol Rev 4:95-100

Gutzwiller KJ (2013) Recreational disturbance and wildlife communities. In: Knight RI, Gutzwiller KJ (eds) Wildlife and recreationists. Island Press, Washington, pp 169-181

Hadwen WL, Arthington AH, Mosisch TD (2003) The impact of tourism on dune lakes on Fraser Island, Australia. Lakes Reserv Res Manag 81:15-26. https://doi.org/10.1046/j.1440-1770.2003.00205.x

HaySmith L, Hunt J (2013) Nature tourism: impacts and management. In: Knight RI, Gutzwiller KJ (eds) Wildlife and recreationists: coexistence through management and research. Island Press, Washington, pp 203-219

Hermanowicz W, Dojldo J, Dożańska W, Koziorowski B, Zerze J (1999) Fizyczno-chemiczne badanie wody i ścieków [Physico-chemical surveys of water and sewages]. Arkady, Poland, Warszawa

Hubendick B (1958) Factors conditioning the habitat of freshwater snails. Bull World Health Organ 18:1072-1080

Jankowski AT, Czylok A (2008) Protection of water ecosystems in urbanized and industrial areas. In: Partyka J, Pociask-Karteczka J (eds) Wody na obszarach chronionych. Instytut Geografii i Gospodarki 
Przestrzennej UJ, Ojcowski Park Narodowy. Komisja Hydrologiczna PTG, Kraków, pp 53-61

Janson E, Gzyl G, Banks D (2009) The occurrence and quality of mine water in the upper Silesian Coal Basin, Poland. Mine Water Environ 28:232-244. https://doi.org/10.1007/S10230-009-0079-3

Jeffries MJ (2011) The temporal dynamics of temporary pond macroinvertebrate communities over a 10 -year period. Hydrobiologia 661: 391-405. https://doi.org/10.1007/s10750-010-0551-x

Knight RL, Temple SA (2013) Wildlife and recreationists: coexistence through management. In: Knight RL, Gutzwiller KJ (eds) Wildlife and recreationists coexistence through management and research. Island Press, Washington, pp 327-333

Kristd AC (2002) Crayfish induce a defensive shell shape in a freshwater snail. Invertebr Biol 121:235-242. https://doi.org/10.1111/j.17447410.2002.tb00063.x

Lakowitz T, Bronmark C, Nystrom P (2008) Tuning in to multiple predators: conflicting demands for shell morphology in a freshwater snail. Freshwat Biol 53:2184-2191

Liddle MJ, Scorgie HRA (1980) The effects of recreation on freshwater plants and animals: a review. Biol Conserv 17:183-206. https://doi. org/10.1016/0006-3207(80)90055-5

Machowski R (2010) Przemiany geosystemów zbiorników wodnych powstałych w nieckach osiadania na Wyżynie Katowickiej. Prace Naukowe Uniwersytetu Śląskiego 2811, Katowice

Machowski R, Noculak M (2014) Anthropogenic change in water bodies in the southern part of the Silesian Upland. Limnol Rev 14:93-100. https://doi.org/10.2478/limre-2014-0010

Manatunge J, Asaeda A, Priyadarshana T (2000) The influence of structural complexity on fish-zooplankton interactions: a study using artificial submerged macrophytes. Environ Biol Fish 58:425-438. https://doi.org/10.1023/A:1007691425268

Maqboul A, Aoujdad R, Fadli M, Fekhaoui M (2014) Population dynamics of Physa acuta (Mollusca: Pulmonata) in the lakes of Rif mountains (northern Morocco, Ouergha watershed). J Entomol Zool Stud 2:240-245

McCune B (1997) Influence of noisy environmental data on canonical correspondence analysis. Ecology 78:2617-2623. https://doi.org/ 10.1890/0012-9658(1997)078[2617:IONEDO]2.0.CO;2

McNicol DK, Wayland M (1992) Distribution of waterfowl broods in Sudbury area lakes in relation to fish, macroinvertebrates, and water chemistry. Can J Fish Aquat Sci 49:122-133. https://doi.org/10. 1139/992-307

Monz CA, Pickering CM, Hadwen WL (2013) Recent advances in recreation ecology and the implications of different relationships between recreation use and ecological impacts. Front Ecol Environ 11: 441-446. https://doi.org/10.1890/120358

Nyström P, Perez JR (1998) Crayfish predation on the common pond snail (Lymnaea stagnalis): the effect of habitat complexity and snail size on foraging efficiency. Hydrobiologia 368:201-208

Oertli B, Joye DA, Castella E, Juge R, Cambin D, Lachavanne JB (2002) Does size matter? The relationship between pond area and biodiversity. Biol Conserv 104:59-70. https://doi.org/10.1016/S00063207(01)00154-9

Pakulnicka J (2008) The formation of water beetle fauna in anthropogenic water bodies. Oceanol Hydrobiol Stud 37:31-42. https://doi.org/10. 2478/v10009-007-0037-y

Palmer MW (1993) Putting things in even better order: the advantages of canonical correspondence analysis. Ecology 74:2215-2230. https:// doi.org/10.2307/1939575

Pamplin PAZ, Almeida TCM, Rocha O (2006) Composition and distribution of benthic macroinvertebrates in Americana Reservoir (SP, Brazil). Acta Limnol Bras 18:121-132

Persson A, Svensson J (2006) Effects of benthivorous fish on biogeochemical processes in lake sediments. Freshw Biol 51:1298-1309. https://doi.org/10.1111/j.1365-2427.2006.01569.x
Pickering SR, Castley JG (2011) A review of the impacts of nature based recreation on birds. J Environ Manag 92:2287-2294. https://doi.org/ 10.1016/j.jenvman.2011.05.005

Rennie MD, Jackson LJ (2005) The influence of habitat complexity on littoral invertebrate distributions: patterns differ in shallow prairie lakes with and without fish. Can J Fish Aquat Sci 62:2088-2099. https://doi.org/10.1139/f05-123

Resh VH, Rosenberg DM (eds) (1993) Freshwater biomonitoring and benthic macroinvertebrates. Chapman and Hall, New York

Růžičková S, Schenková J, Weissová V, Helešic J (2014) Environmental impact of heated mining water on ciltellate (Annelida: Clitellata) assemblages. Biologia 69:1179-1189. https://doi.org/10.2478/ s11756-014-0424-2

Rychała A, Benndorf J, Buczyński P (2011) Impact of pH and conductivity of species richness and community structure of dragonflies (Odonata) in small mining lakes. Fundam Appl Limmnol 179:4150. https://doi.org/10.1127/1863-9135/2011/0179-0041

Rzętała M, Jaguś A (2012) New lake district in Europe: origin and hydrochemical characteristics. Water Environ J 26:108-117. https://doi.org/10.1111/j.1747-6593.2011.00269.x

Rzętała M, Rahmanov O, Malik I, Oleś W, Pytel S (2006) Study the use artificial water reservoirs in Silesian upland (Southern Poland) as element of cultural landscape. Ekologia (Bratislava) 25:212-220

Saddozai S, Baloch WA, Achakzai M, Memon N (2013) Population dynamics and ecology of freshwater gastropods in Manchar Lake Sindh, Pakistan. J Anim. Plant Sci 23:1089-1093

Spyra A (2017) Acidic, neutral and alkaline forest ponds as a landscape element affecting the biodiversity of freshwater snails. Naturwissenschaften 104:73

Spyra A (2018) Distribution patterns and habitat requirements of freshwater snails in man-made ponds. Ann Zool Fenn 55:1-14

Spyra A, Strzelec M (2014) Identifying factors linked to the occurrence of alien gastropods in isolated woodland water bodies. Naturwissenschaften 101:229-239. https://doi.org/10.1007/ s00114-014-1153-7

Szafer W, Kulczyński S, Pawłowski B (1986) Rośliny Polskie [Polish plants]. PWN, Warszawa

Taylor TP, Erman DC (1979) The response of benthic plants to past levels of human use in high mountain lakes in Kings Canyon National Park, California, USA. J Environ Manag 9:271-278

ter Braak CJF, Verdonschot PFM (1995) Canonical correspondence analysis and related multivariate methods in aquatic ecology. Aquat Sci 57:255-289

Turner AM, Chislock MF (2007) Dragonfly predators influence biomass and density of pond snails. Oecologia 153:407-415. https://doi.org/ 10.1007/s00442-007-0736-9

Uzunov J, Košel V, Sládeček V (1988) Indicator value of freshwater Oligochaeta. Acta Hydrochim Hydrobiol 16:173-186. https://doi. org/10.1002/aheh.19880160207

Vaske JJ, Decker DJ, Manfredo MJ (2013) Human dimensions of wildlife management: an integrated framework for coexistence. In: Knight RI, Gutzwiller KJ (eds) Wildlife and recreationists: coexistence through management and research. Island Press, Washington, pp 33-49

Venohr M, Langhans SD, Peters O, Hölker F, Arlinghaus R, Mitchell L, Wolter C (2018) The underestimated dynamics and impacts of water-based recreational activities on freshwater ecosystems. Environ Rev 26(2):199-213. https://doi.org/10.1139/er-2017-0024

Winkelmann C, Hellmann C, Worischka S, Petzoldt T, Benndorf J (2011) Fish predation affects the structure of a benthic community. Freshw Biol 56:1030-1046. https://doi.org/10.1111/j.1365-2427.2010.02543.x

Publisher's note Springer Nature remains neutral with regard to jurisdictional claims in published maps and institutional affiliations. 